Summer 2015

\title{
The Best Interests of a Trafficked Adolescent
}

Anah Hewetson Gouty

Indiana University Maurer School of Law, anah.h.gouty@gmail.com

Follow this and additional works at: https://www.repository.law.indiana.edu/ijgls

Part of the International Law Commons, Juvenile Law Commons, and the Legislation Commons

\section{Recommended Citation}

Hewetson Gouty, Anah (2015) "The Best Interests of a Trafficked Adolescent," Indiana Journal of Global Legal Studies: Vol. 22 : Iss. 2 , Article 15.

Available at: https://www.repository.law.indiana.edu/ijgls/vol22/iss2/15

This Note is brought to you for free and open access by the Law School Journals at Digital Repository @ Maurer Law. It has been accepted for inclusion in Indiana Journal of Global Legal Studies by an authorized editor of Digital Repository @ Maurer Law. For more information, please contactrvaughan@indiana.edu.

\section{$\Psi$}

JEROME HALL LAW LIBRARY

INDIANA UNIVERSITY

Maurer School of Law
Bloomington 


\title{
The Best Interests of a Trafficked Adolescent
}

\author{
ANAH HEWETSON GOUTY*
}

\begin{abstract}
For decades, the world has faced a tremendous obstacle in locating trafficking victims and their perpetrators. The United States has enacted the Trafficking Victims Protection Act (TVPA) and implemented a system of Trafficking in Persons Reports (TIPs) to track domestic progress. Nonetheless, even more challenging than addressing adult trafficking is conquering the rampant existence of child trafficking, which inherently has its own unique challenges. Child trafficking comes in many forms and affects different regions of the world in various ways. Misunderstanding precisely what constitutes trafficking is one of the obstacles to ridding the world of its existence. Moreover, the victimsadolescents-are also misunderstood, mislabeled, and as a result, left to the hands of their perpetrators rather than brought to safety by trained specialists. The United States, as a global leader, has a role to play in resolving the ambiguities within child trafficking laws. It has a duty to create and enforce child-specific remedies and protections that recognize an adolescent's own best interests. Furthermore, the United States can help diminish predator success by empowering youth, recognizing their constitutional rights, and giving them a voice within the nation's legal framework. Those countries that have enacted the Convention on the Rights of the Child (CRC) have already adopted these ideals of empowering youth. By failing to enact the CRC and with case law precedent, the United States has sent a message that an adolescent's own best interests are not defined by him or herself, but by others. Thus, the United States has created an impediment in the way of terminating child trafficking operations.
\end{abstract}

\section{INTRODUCTION}

Trafficking occurs internationally from country to country, as well as internally within a nation's own borders. Traffickers, who cunningly capitalize on children's vulnerabilities, such as hunger, poor education, lack of supervision, poverty, or low self-esteem, exploit children daily

Indiana Journal of Global Legal Studies Vol. 22 \#2 (Summer 2015)

(C) Indiana University Maurer School of Law 
and in large networks. "Adolescents are a high risk group. There is danger that [governments] focus too much on the risk to babies and very young children ...."1 Moreover, to fight child trafficking most efficiently, governments, non-governmental organizations (NGOs), and agencies must empower those who know most about it-adolescent survivors.

The United States will more effectively lead the global war against child trafficking by enacting a Child Trafficking Victims Protection Act to call attention to the nature of child-including adolescenttrafficking. ${ }^{2}$ More specific legislation identifying vulnerabilities of adolescents and characteristics of child trafficking will help prevent further trafficking. Child trafficking laws are not specific enough to help with one of the biggest challenges to slowing child traffickingidentification of child victims. To act in the child's best interests, legislatures should be more specific when identifying problems with trafficking of children. In addition, the United States should follow the global consensus and empower youth with more constitutional rights, both substantive and procedural, as an answer to what is in the best interests of the child. United States case law places emphasis on giving parents and the state control over defining what is in the best interests of the child; however, trafficked adolescents have more opportunity to move beyond a victim state when empowered with rights to determine their own best interests and help resolve the child-trafficking problem. Because children are undeniably vulnerable, providing each child with unbiased counsel would not only address the concern of vulnerability, but would also afford the child a more substantiated opportunity to reach a just result.

\footnotetext{
* Executive Editor, Indiana Journal of Global Legal Studies, Volume 22; JD 2015, Indiana University Maurer School of Law-Bloomington; B.A. History, B.A. U.S. Government, 2012, University of Virginia-Charlottesville. I would like to thank the brilliant and uplifting Professor Roger Levesque for his guidance and faithful editing throughout the Note writing and reviewing process. His course inspired me to advocate for a valuable group of Americans that are legally underprivileged-children. I would also like to thank my family and husband for their unceasing patience, support, and love in all that I do.

1. Jenny J. Pearce, Patricia Hynes \& Silvie Bovarnick, Trafficked Young PEOPLE: BREAKING THE WALL OF SILENCE 9 (2013).

2. The Child Trafficking Victims Protection Act is the unenacted bill, H.R. 2624 that was introduced to a congressional committee on July 8, 2013. A congressional committee was reviewing the bill, but it did not get past the committee stage. Had it progressed, the bill would have had a small chance, $2 \%$, of passing in the House. The bill's mission is "[t]o provide for enhanced protections for vulnerable unaccompanied alien children and female detainees." See Child Trafficking Victims Protection Act, H.R. 2624, 113th Cong. (2013), available at https:/www.govtrack.us/congress/bills/113/hr2624.
} 


\section{DEFINING TRAFFICKING AND CLARIFYING MisconCEPTIONS}

Trafficking is complex and must be defined in a broad context. This is a result of globalization's characterization of child trafficking. Moreover, there are several misconceptions about the reality of trafficking due to the media's portrayal of the crime as well as a lack of research data. First, trafficking and smuggling are not the same event; the two crimes have intrinsic differences. Second, trafficking occurs in many different forms, not just sexual exploitation. Although sexual exploitation is recorded as the most frequently practiced method of exploitation, the reports are unclear as to whether this is because sexual exploitation is identified more often, or because it actually occurs more often. ${ }^{3}$ And last, while women and children make up a larger portion of trafficking victims, males are exploited in significant numbers as well.

\section{A. Defining Trafficking}

"Human trafficking is thought to be the third most profitable organised criminal activity in the world, after weapons and narcotics." 4 Its reach is expansive and affects almost all countries around the globe, whether they are receiving trafficked persons, serving as the trafficked person's country of origin, or harboring trafficking activities within their borders. In 2000, the United Nations Protocol to Prevent, Suppress and Punish Trafficking in Persons, Especially Women and Children, Supplementing the United Nations Convention Against Transactional Organized Crime defined trafficking as:

[T] he recruitment, transportation, transfer, harbouring or receipt of persons, by means of the threat or use of force or other forms of coercion, of abduction, of fraud, of deception, of the abuse of power or of a position of vulnerability or of the giving or receiving of payments or benefits to achieve the consent of a person having control over another person, for the purpose of exploitation. ${ }^{5}$

3. PeARCE ET AL., supra note 1 , at 4.

4. Id. at 2 .

5. Protocol to Prevent, Suppress and Punish Trafficking in Persons, Especially Women and Children, Supplementing the United Nations Convention Against Transnational Organized Crime, G.A. Res. 55/25, U.N. Doc. A/RES/55/25 (Jan. 8, 2001) [hereinafter Palermo Protocol]. 
This Protocol (the Palermo Protocol) is the "first global legally binding instrument with an agreed definition on trafficking in persons."6 "[S]ocial scientists estimate that [about] 27 million men, women, and children are trafficking victims at any given time." 7 Despite this large number of estimated trafficked victims, the Trafficking in Persons Report for 2013 only identified 40,000 victims in the last year. ${ }^{8}$ The solution to trafficking will arise when those two statistics meet; that is, when the number of estimated trafficked people are also identified as trafficked survivors.

"According to UNICEF, [of these trafficked persons,] some 1.2 million children may be trafficked each year." 9 Children are defined by the Palermo Protocol of 2000 as any persons under the age of eighteen. ${ }^{10}$ The Protocol explains that no person under the age of eighteen, or any person for that matter, can consent to being trafficked. ${ }^{11}$

\section{B. Trafficking v. Smuggling}

'While the terms 'trafficking' and 'smuggling' have been [and often are] used interchangeably, there are [many] distinctions between the two concepts." 12 The UK Department for Children, School and Families, a government agency, explained the distinction in Safeguarding Children Who May Have Been Trafficked: "'[H]uman smuggling' describes an event whereby 'immigrants' or 'asylum seekers' pay people to help them enter the country illegally, after which there is no longer a relationship between the parties." 13 In contrast, trafficked young people are coerced or deceived by the trafficker, and consequently forced into exploitation. The trafficked young person is victim to the trafficker, who has an ongoing exploitative, controlling relationship with the trafficked person. Also, smuggling involves the illegal crossing of international borders; yet, trafficking can exist internally and transnationally. In sum, smuggling is a crime against the state, and trafficking is a human

6. United Nations Convention Against Transnational Organized Crime and the Protocols Thereto, U.N. OFFICE ON DRUGS \& CRIME, http:/www.unodc.org/unodc/treaties/ CTOC/ (last visited Nov..15, 2013.)

7. Victim Identification: The First Step in Stopping Modern Slavery, U.S. DEP'T OF STATE, in TRAFFICKING IN PERSONS REPORT 7 (2013), http://www.state.gov/documents/ organization/210737.pdf [hereinafter U.S. DEP'T OF STATE].

8. See id.

9. PEARCE ET AL., supra note 1, at 2.

10. See Palermo Protocol, supra note 5, at 2.

11. See id.; see also PEARCE ET AL., supra note 1, at 2.

12. PEARCE ET AL., supra note 1, at 19 (citing U.K. DEP'T FoR ChILdRen, SCH. \& Families, Safeguarding ChildRen Who May Have Been Trafficked, (2007)).

13. See id. 
rights violation. ${ }^{14}$ This distinction is important because it shows the expansive and exploitative reach of trafficking.

\section{Many Forms of Exploitation}

Child trafficking comes in many forms and is done for many different purposes. Although research concerning trafficked young people is increasing, it focuses on trafficking as sexual exploitation or prostitution. ${ }^{15}$ Despite this, trafficking of young people occurs in many forms of exploitation including the following: forced domestic labor, enforced criminality, intracountry adoption, child soldiering, child mutilation, and more subtle forms of exploitation, such as doing domestic work in exchange for a small sum to the victim's parents. The International Labour Organization (ILO) estimates that children make up 26 percent of forced labor victims. ${ }^{16}$ Because trafficking for sexual exploitation receives more attention, there is a large assumption that trafficking affects girl, rather than boy, victims; however, males are victim to child trafficking too, even for sexual exploitation. An international NGO dedicated to assisting abandoned children, Casa Alianza, based in Central America, conducted research in twenty Honduran cities and discovered forty-two of the 1,019 trafficked minors were males. ${ }^{17}$ In the Central America-Mexico migration circuit, Casa Alianza discovered a case where a boy was purchased for $\$ 3,000.18$ Although occurring less often, a particular sect of traffickers victimizes young males too. Because there is a misconception that young males are not trafficked, many of them are not discovered as victims.

\section{AMBIGUITIES RESULT IN LOSS}

Identifying child victims is especially challenging because children, already wary of strangers, are labeled inconsistently as "missing," "separated unaccompanied," or "illegal immigrant," rather than uniformly as "trafficked victim" - a label that would signal that the child

14. See id. at 20.

15. See id. at 4.

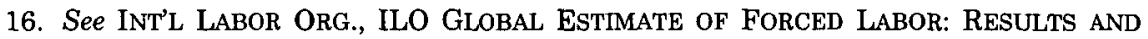
METHODOLOGY 14 (2012).

17. See Trafficking and Sexual Exploitation of Boys and Male Adolescents in Central America, U.N. OFFICE ON DRUGS \& CRIMES (June 4, 2009), http://www.ungift.org/ungift/ en/stories/trafficking-and-sexual-exploitation-of-boys-and-male-adolescents-in-central-

america.html.

18. See id. 
needs immediate help from child protection services. ${ }^{19}$ These victims face linguistic and cultural barriers as well as deportation threats that create a disconnect with specialists and law enforcement. In addition to these obstacles, adolescents in general are already prone to behavioral challenges, making them even more vulnerable as specialists become less eager to help. Because of these diverse backgrounds and special obstacles, adolescents should be met with an approach that best fits their interests and needs. For example, Spanish-speaking victims need Spanish-speaking teams to communicate and to abrogate fear and confusion; sexually exploited female victims might benefit from female workers who are less threatening than their male counterparts. What are the responses of the United States and other areas of the globe to children in such adversity-facing life-altering situations-and what legal concepts motivate these nations? Are they motivated by what is in the best interests of the adolescent?

\section{A. At Points of Entry}

Upon arriving at their new destinations, children can be met by a number of different individuals. Medical personnel, police officers, border patrol agents, interpreters, and other specialists are in a position to both encounter and recognize young trafficking victims. The special vulnerabilities of children not only heighten the likelihood that they will be trafficked, but also hinder the ability to gather information that enables law enforcement and social service personnel to move children forward past their vulnerable states. Trafficked young children can react in several ways upon being discovered, and the care given to easing their fears is crucial to not only capturing the trafficker, but more importantly, aiding the child victim to reach a place of agency from which he can move forward to a new, better life.

Identifying victims remains one of the largest obstacles hindering the prevention of trafficking. The U.S. Department of State explains, "[c]ase after case has emerged in which government officials come in contact with a trafficking victim and fail to recognize the characteristics of the crime." 20 The critical point of entry, or moment of identification of the victim, depends on the training and intuitiveness of the individuals who meet trafficked young children. The ability to succeed in identifying child victims of trafficking relies on multiple institutions staffed by members with proper training.

19. See generally PEARCE ET AL., supra note 1.

20. U.S. DEP'T OF STATE, supra note 7 , at 10 . 
Another challenge to identification is an inconsistency in labeling the trafficked child. The U.S. Department of Justice explains, "[W] hen authorities misclassify or fail to identify victims[,] the victims lose access to justice." 21 Trafficked children can be labeled as missing, separated, unaccompanied, trafficked, or illegal immigrant. A lack of consistency in labeling has been detrimental to research that is necessary to prevent the increase of child trafficking globally. Moreover, if child victims are classified as illegal immigrants, they are denied the child protection services they need. ${ }^{22}$ The most prominent misidentification of a victim is one that labels him or her an illegal immigrant.

\section{Language Barriers, Deportation Threats}

Children often do not seek help for a number of reasons. One major threat is deportation. In its Trafficking Report of 2013, the U.S. Department of State explains, "when authorities misidentify trafficking victims as illegal migrants or criminals deserving punishment, those victims can be unfairly subjected to additional harm, trauma, and even punishment such as arrest, detention, deportation, or prosecution." 23 The anxiety and fear that stem from these threats will only be escalated in the minds of children. In Trafficking Young People: Breaking the Wall of Silence, researchers using their case study from the United Kingdom understand and relate that there is "need for services to be available first and foremost for [children] at the point of entry to the country, including access to a place of safety ... prior to any questions emerging about [an] 'immigration status' or 'age assessment'." 24

Children's fear of deportation threat is only one barrier to receiving assistance. Service providers may also misunderstand children due to cultural barriers and-even more damaging to establishing a relationship of trust-language barriers. Four research teams completed a study of the six riparian countries of the Mekong River, including Yunnan Province in China, Myanmar, Laos, Thailand, Cambodia, and Vietnam. The study found that one of the biggest difficulties in assisting trafficked children is "language barriers and communication obstacles" that "make it more difficult to gain access to information on the children's problems and needs" and either result in

\footnotetext{
21. Id. at 9 .

22. Id.

23. Id.

24. PEARCE ET AL., supra note 1, at 121.
} 
providing "not wanted aid and support" or giving support too late. ${ }^{25}$ These hurdles-misidentification, cultural misunderstandings, and language barriers-all serve to inhibit the ability of child trafficking victims to trust officials and thus reach a safer life.

\section{Not Abusing the System}

Despite the stereotyping of adolescents as troublemakers, their "behavioral and cognitive systems mature at different rates," and "this period is often one of increased vulnerability and adjustment." 26 In light of these vulnerabilities, adolescence is a period in which children already have "increased risk for the onset of . . . emotional and behavioral problems, including depression, violent delinquency and substance abuse." 27 Traffickers recognize the vulnerabilities in teens and capitalize on them. "Traffickers use threats, intimidation, and violence, as well as deception and trickery, to force or lure victims" into trafficking. ${ }^{28}$ In this period of vulnerability, adolescents are perfect targets of predatory traffickers. For example, the average national age at which girl victims are first exploited for sex trafficking is twelve to fourteen, indicating the prevalence of targeting adolescent females for their vulnerable nature. ${ }^{29}$ Children in early adolescence (ages eleven to fourteen) have cognitive development "dominated by concrete thinking, egocentrism, and impulsive behavior," which is more easily manipulated by traffickers. ${ }^{30}$

Predators also find locales where adolescents are comfortable yet approachable, such as outside areas on school grounds, shopping malls, or parks. These emotional vulnerabilities in adolescents, from which traffickers profit, also highlight adolescent trafficked victims' needs upon identification. Coupling their vulnerabilities with the effects of trafficking, adolescents' needs for mental health services and treatment are substantial. In consequence, children trafficked during their adolescence require specialized services approached with openness

25. Kritaya Archavantikul, Combating the Trafficking in Children and Their Exploitation in Prostitution and Other Intolerable Forms of Child Labour in Mekong Basin Countries, InST. FOR POPULATION \& SOC. RESEARCH, MAHIDOL UNIV. AT SALAYA, (1998).

26. Laurence Steinberg, Cognitive and Affective Development in Adolescence, 9 TRENDS CoGNITIVE SCI. 69, 69 (2005).

27. Id.

28. Heather J. Clawson, et al., U.S. Dep't Health \& Human Serv., Human Trafficking InTo and WiThin THE UNITED STATES: A REVIEW OF THE LiTERATURE 8 (2009).

29. See id.

30. Jamie Stang \& Mary Story, Adolescent Growth and Development, in GuIDELINES FOR ADOLESCENT NUTRITION SERVICES 1, 6 (2005). 
rather than assumptions about rowdy, troublesome teenagers. Despite this need, adolescent victims are often suspected of abusing the system to get help or considered "apparently threatening aggressive young person[s]" because they are in their teen years. ${ }^{31}$

There are other psychological obstacles that child trafficked victims confront. Adolescents can suffer from "Stockholm Syndrome - where due to unequal power, victims create a false emotional or psychological attachment to their controller."32 This may cause the adolescent to run back to his trafficker or refuse to open up to specialists and law enforcement officers. As a result of all these challenges, adolescent trafficked victims are more intimidating to specialists than young children who personify innocence and have less independent thinking. ${ }^{33}$ This makes a positive relationship between trafficked victims and care providers difficult to accomplish. Victims already "may not trust the provider and may not understand or believe the provider is willing to help." 34 The challenges in helping adolescent trafficked survivors are prominent and must be confronted so that adolescents can realize their own best interests.

\section{B. The Best Interests of the Child Standard: Do a Child's Rights Matter?}

Since its introduction in 1989, the United Nations Convention on the Rights of a Child (CRC) has been signed by every nation in the United Nations besides Somalia and the United States. ${ }^{35}$ With such a strong following, human rights activists have heralded the CRC as one of the best pieces of human rights legislation ever passed. ${ }^{36}$ The CRC is based on four principles: (1) children should be free from discrimination; (2) the best interests of the child standard should be used; (3) children should develop to their full potentials; and (4) children's views are important and should be heard. ${ }^{37}$ The United Nations' purpose in adopting the "best interest of the child" standard was to empower children legally and encourage states to recognize that children have

31. PEARCE ET AL., supra note 1, at 10.

32. Michael Bradley, Human Trafficking: Why Do So Many Victims Refuse Help?, BBC NEwS (Oct. 17, 2013, 5:57 AM), http:/www.bbc.com/news/uk-england-24548143.

33. PEARCE ET AL., supra note 1 , at 10.

34. ClAWSON ET AL., supra note 28 , at 22.

35. The Threat from International Treaty Law, PARENTALRIGHTS.oRg, http://www. parentalrights.org/index.asp?SEC=\%7B53D4DCA7-5899-4242-B244-54A253AFC137\%7D (last visited Nov. 8, 2013).

36. Rochelle D. Jackson, The War Over Children's Rights: And Justice for All? Equalizing the Rights of Children, 5 BUFF. HUM. RTS. L. REV. 223, 225 (1999).

37. See The Convention on the Rights of the Child, UNICEF, www.unicef.org/crc/ files/Guiding_Principles.pdf (last visited Nov. 9, 2013). 
rights too. Although in theory this standard sounds like it would only result in the best interests of children, whether this standard has really resulted in a recognition of a child's fundamental rights is debatable on an international scale and almost certainly not the case in the United States.

The United States refused to adopt the CRC, yet it uses a "best interest of the child" standard within its child-welfare system. ${ }^{38}$ Where is the disconnect between the two? A review of United States case law in relation to determining a child's welfare and what is "in the best interests of the child" reveals that parental decisions and rights to rear children are put before a child's voice-or at least given the most emphasis-in judicial decisions. For example, in Wisconsin v. Yoder, a 1972 case, the Supreme Court established that Amish parents were allowed to withdraw their children from school for religious purposes, declaring the state law that all children must attend public or private schooling until age sixteen unconstitutional because it infringes upon the parents' First and Fourteenth Amendment rights to freedom of religion and due process. ${ }^{39}$ The majority opinion does not mention the rights of the child to freedom of religion, or freedom to attend or not attend a particular school; instead, the Court focuses on the parental rights to determine what is best for their children. Similarly, the Supreme Court in Troxel $v$. Granville, a more recent case, denied grandparents visiting time with their grandchildren despite the Washington state law that allowed visiting "at any time" whenever "visitation may serve the best interest of the child." 40 The Court determined that the law infringed on the mother's substantive "due process right to make decisions concerning the care, custody, and control of her daughters." 41 Maybe the children desired to spend time with grandparents more often than the mother's wishes; yet, again, parental rights were upheld as determinative of the best interests of the child.

Perhaps the best example of U.S. case law exemplifying the challenge in weighing the "best interests of the child" standard with a standard granting a "child's rights" to make decisions is in abortion cases that involve minors. Although most medical treatment of minors

38. For example, see Determining the Best Interests of a Child, CHILD WELFARE INFORMATION GATEWAY, www.childwelfare.gov (2012).

39. See Wisconsin v. Yoder, 406 U.S. 205 (1972) (determining parental rights, in particular Amish parental rights, in rearing children as well as their rights to be free in religion rights shall not be trumped by the state unless there is a compelling reason).

40. Troxel v. Granville, 530 U.S. 57, 60 (2000) (holding a parent's substantive due process rights in raising her children cannot be infringed by the state unless the state has a compelling reason, such as to prevent harm to the child).

41. Id. at 57 . 
requires consent from their parents, the requirement of parental consent is set aside under certain circumstances. ${ }^{42}$ The Mature Minor Doctrine allows legally valid consent from competent minors for routine beneficial medical treatment as well as emergency situations. ${ }^{43}$ In addition to this, the Supreme Court has recognized a child's right to bypass parental consent to an abortion with judicial authorization when the judge has determined the abortion would be in the minor's best interests. 44 The minor female has rights in this situation under the Due Process Clause. The right is substantive due process, rather than procedural; it is a right to protect her bodily integrity and a right to privacy. The Court's use of the "best interests of the child" standard in this case and subsequent cases allowing parental bypass measures no longer puts parents' right to rear their child above the child's liberty interests. Although many state laws still require parental consent, the parental bypass through judicial hearing makes it seem as though the Court "first divested parents of a right" they had for fifty years, then "endowed the state with it." 45

This case law illustrates the belief that what is in the best interest of the child can be determined by asking the parents, and in few cases, by asking the state. It is very rare in U.S. case law that children have their substantive due process rights to privacy, bodily integrity, family, and intimacy protected to preserve their wishes. In conjunction, it is just as unusual that a child be afforded his freedom to choose religion and association, aforementioned in the groundbreaking Yoder and Troxel cases. The "best interests of the child" standard in the United States is one that recognizes a parent's right to rear children and the state's right to protect a child from harm more than it ever affords a child, or a more capable adolescent, his fundamental rights. These conceptions in U.S. case law differ from the approach taken by the United Nations' CRC that endows children with rights while also applying a "best interests of the child" standard.

\section{ChILD TRAFFicking LEGAL RAMifications HERE AND ABROAD}

The United Nations has remained dedicated to the fight against trafficking since the Palermo Protocol in 2000. Following suit, the U.S. federal and state governments have issued trafficking laws to help

42. See Elizabeth S. Scott, The Legal Construction of Childhood 1-25 (Univ. of Va. Sch. of Law Pub. Law \& Legal Theory Research Papers, Working Paper No. 00-18, 2000).

43. Id. at 21 .

44. Bellotti v. Baird, 443 U.S. 622, 630 (1979) (plurality opinion).

45. Martin Guggenheim, Minor Rights: The Adolescent Abortion Cases, 30 HofsTRA L. REV. 589, 645 (2002). 
prevent, protect, and prosecute trafficking. Because trafficking affects both hemispheres, the United States has created an initiative to improve legislation in all areas of the globe. With U.N. sponsors, NGOs, and other human rights groups supporting them, developing countries are now issuing child-trafficking laws and creating regional movements to stop it. Nonetheless, high poverty areas like the Greater Mekong Subregion (GMS) in Asia and countries in Africa continue to serve as hubs for child trafficking networks. ${ }^{46}$ However, research not only in the Americas, but also in Asia and Africa, reveals that countries are making efforts to improve legislation.

\section{A. The United States}

\section{Federal Action}

"For far too long in America, the attitude toward child trafficking has been that it's terrible, but happens somewhere else,' says Ernie Allen, president of the International Centre for Missing \& Exploited Children in Alexandria, Virginia. 'But this problem exists right here on Main Street, USA."47 Despite this misconception, "more than 10,000 foreign children are brought here annually as sex slaves, or indentured laborers." 48 "A $\$ 9.5$ billion-a-year industry, human trafficking is on the rise and has been reported in all fifty states." 49 In addition, California holds three of the Federal Bureau of Investigation's (FBI) highest childsex-trafficking areas: Los Angeles, San Francisco, and San Diego. ${ }^{50}$

The United States passed its first comprehensive law to protect victims of human trafficking on October 28, 2000, which was entitled, Trafficking Victims Protection Act (TVPA). ${ }^{51}$ The legislation is based on three main goals: (1) to prevent human trafficking abroad; (2) to protect victims and help them rebuild their lives in the United States with government support; and (3) to prosecute traffickers with harsh

46. UNIAP: Where We Work, U.N. INTER-AGENCY PROJECT ON HUMAN TRAFFICKING, www.no-trafficking.org/where.html (last visited Nov. 13, 2013).

47. Molly M. Ginty, Protecting the Powerless: Child Trafficking in the United States, NAT'L COUNCIL OF JEWISH WOMEN, www.ncjw.org/content_236.cfm (last visited Nov. 7, 2013).

48. Id.

49. Id.

50. 11 Facts About Human Trafficking, DoSOMETHING.ORG, http://www.dosomething.org/ facts/11-facts-about-human-trafficking (last visited Nov. 25, 2013).

51. See Summary of the Trafficking Victims Protection Act (TVPA) and Reauthorizations, ALLIANCE TO END SLAVERY \& TRAFFICKING, http://endslaveryandtrafficking. org/fy2014/Relevant-Authorization-Statutes.php (last visited Nov. 8, 2013). 
penalties. ${ }^{52}$ Since the legislation's enactment in 2000, the United States has passed the Trafficking Victims Protection Reauthorization Act of 2003 , 2005, 2008, and 2013 to renew its dedication to prevent trafficking, protect trafficked victims, and prosecute traffickers. ${ }^{53}$ President Obama signed the latest reauthorization of TVPA on March 7, 2013. ${ }^{54}$ The reauthorization, led by Senator Leahy, renews federal antitrafficking programs, provides specialist services for survivors, grants prosecutors new tools to go after traffickers, and enhances partnerships with other countries to gain a special focus on preventing child trafficking. ${ }^{55}$ With these actions, the U.S. government recognized the necessity of targeting child trafficking more heavily.

In addition to the Act, each year the United States offers a Trafficking in Persons Report (TIP) that serves as the "world's most comprehensive resource of governmental anti-human trafficking efforts and reflects the U.S. government's commitment to global leadership on this key human rights and law enforcement issue."56 The U.S. government uses the TIP Report to gauge other countries around the globe in their ability to combat human trafficking. "In the TIP Report, the [U.S. Government] places each country onto one of three tiers based on the extent of their governments' efforts to comply with the 'minimum standards for the elimination of trafficking' found in Section 108 of the TVPA." 57 If a country is ranked in Tier 1, that country has "acknowledged the existence of human trafficking, made efforts to address the problem, and complies with the TVPA's minimum standards." 58

\section{State Action}

In addition to the TIP Report to help countries around the globe, the United States government has recognized the importance of fighting

52. Derek Pennartz, The Irony of the Land of the Free: How Texas Is Cleaning Up Its Human Trafficking Problem, 12 TEX. TECH. ADMIN. L.J. 367, 372 (2011) (quoting Office of the Attorney General, The Tex. Response to Human Trafficking Rep. to the 81st Leg., at 10 (2008)).

53. See Current Federal Laws, POLARIS, http://www.polarisproject.org/what-wedo/policy-advocacy/national-policy/current-federal-laws (last visited Oct. 24, 2013).

54. Trafficking Victims Protection Reauthorization Act, ALLIANCE TO END SLAVERY \& TRAFFICKING, http://www.endslaveryandtrafficking.org/trafficking-victims-protectionreauthorization-act (last visited Nov. 13, 2013).

55. Id.

56. Trafficking in Persons Report, U.S. DEP'T OF STATE, www.state.gov/j/tip/rls/ tiprpt/index.htm (last visited Nov. 13, 2013).

57. Id.

58. $I d$. 
human trafficking domestically. The National Human Trafficking Resource Center (NHTRC), a program of Polaris Project, a Washington D.C.-based NGO that works on the issue of human trafficking, has a hotline that is available twenty-four hours a day, seven days a week, and every day of the year to assist callers offering a tip, wanting antitrafficking services, or requesting information about the fight against human trafficking. ${ }^{59}$

Along with this service provided by NHTRC, the Polaris Project reports state rankings on human trafficking laws within the United States each year. "In 2013, 39 states passed anti-trafficking laws and 32 are now ranked in Polaris Project's top Tier 1 category . . . "60 Last year there were only twenty-one states in Tier 1.61 These ratings are based on statutes enacted by the states and the states' abilities to make improvements through enacting legislation. ${ }^{62}$ Legislation that improves a state's rating may assign asset forfeiture as a punishment for traffickers, promulgate a plan to better train law enforcement, or allow sex trafficking victims to vacate prostitution charges.63 "In July [2013], the Uniform Law Commission (ULC) adopted a uniform act to guide state legislatures when drafting legislation to combat human trafficking . . . "64 The American Bar Association (ABA) has approved the resolution and supports the ULC's uniform act. ${ }^{65}$ With the act's passing, many states are showing improvement in their anti-trafficking laws; however, the Polaris Project explains that, in particular, mountain states lag behind, especially in their victim assistance measures. ${ }^{66}$ Due to awareness and organizations like the Polaris Project, there has been significant progress in combatting human trafficking in the United States on a state level with legislation. Now only two states, West Virginia and Wyoming, have not enacted anti-human trafficking laws. ${ }^{67}$

Besides incentives from organizations and projects like Polaris, big events that attract global attention may encourage states to make

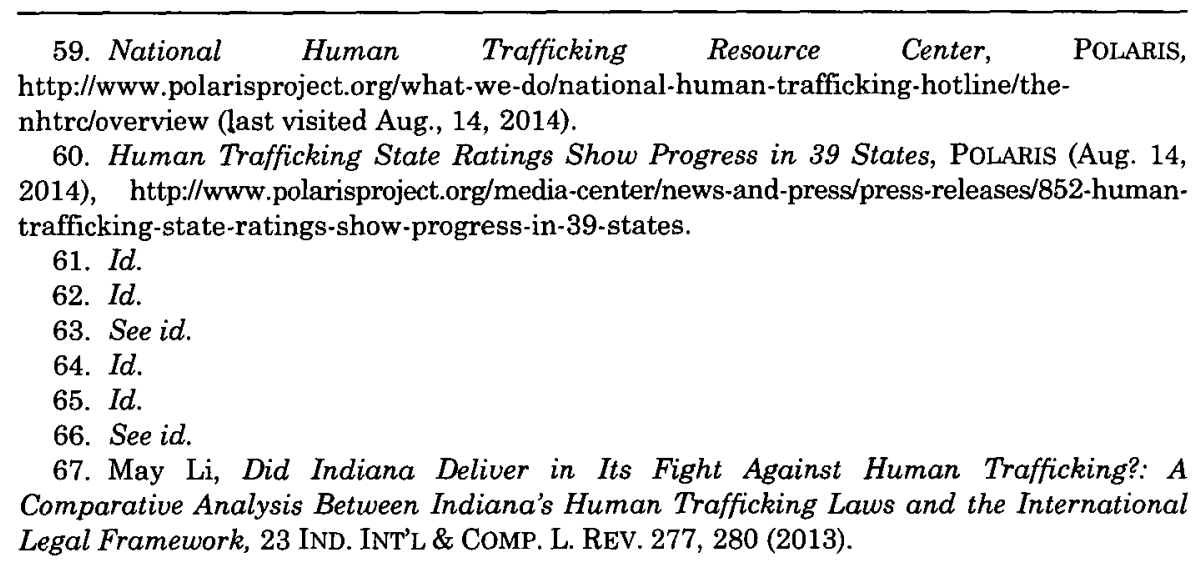


improvements. More specifically, states hosting or planning to host the Super Bowl often make improvements in their human trafficking laws prior to the event to ensure a safe, hospitable environment for not only U.S. citizens, but also international visitors. On November 17, 2010, Texas Attorney General Greg Abbott convened the Texas Human Trafficking Prevention Task Force to reveal its progress as well as to prepare for Super Bowl XLV.68 Abbott referred to the Super Bowl as "the biggest human trafficking event in the United States." 69 Similarly, on January 30, 2012, Indiana passed new human trafficking legislation in preparation for the NFL's Super Bowl Event on February 5, 2012.70 In that same vein, Cindy McCain explained her worry about Arizona, a state ranked in Tier 3 above only four other states (in Tier 4), as follows: "I believe [we have] the moral obligation, to strengthen the state's trafficking laws before January 2015, when the Super Bowl comes to Arizona."71Activities that receive global recognition, like the Super Bowl, require state governments to be one step ahead of traffickers who capitalize on such opportunities. It is unfortunate that these events, rather than the outrageous denial of human rights, are what trigger a state to action; nonetheless, better trafficking laws are a silver lining.

\section{B. The United Nations}

As mentioned in the introductory section, ${ }^{72}$ the United Nations Protocol to Prevent, Suppress and Punish Trafficking in Persons, Especially Women and Children, Supplementing the U.N. Convention on Transactional Organized Crime, or the Palermo Protocol, held in 2000 , is the most widely recognized piece of legislation on human trafficking. In particular, article 3 of the Protocol "is meant to provide consistency and consensus around the world on the phenomenon of trafficking in persons."73 Article 5 not only recommends drafting domestic legislation to criminalize the conduct explained and defined in article 3 , but also recommends a more comprehensive definition of

68. Pennartz, supra note 52 , at 368 .

69. $\mathrm{Li}$, supra note 67 , at 281 .

70. Id. at 280.

71. Cindy McCain, McCain: State Must Combat Human Trafficking, AZ CENTRAL (Mar. 15, 2013, 7:00 PM), http://archive.azcentral.com/opinions/articles/20130313mccain-statemust-combat-human-trafficking.html.

72. See supra Part I.A., which introduces the Palermo Protocol in this paper.

73. Human Trafficking, U.N. OFFICE ON DRUGS AND CRIME, http://www.unodc.org/ unodc/en/human-trafficking/what-is-human-trafficking.html?ref=menuside (last visited Oct. 18, 2013). Human Trafficking, U.N. OfFICE oN DRUGS AND CRIME, http://www.unodc.org/unodc/en/human-trafficking/what-is-human-trafficking.html?ref= menuside (last visited Oct. 18, 2013). 
trafficking; as a result, attempting trafficking, serving as an accomplice to trafficking, and organizing trafficking are all crimes. ${ }^{74}$

With a focus on child trafficking, the United Nations' CRC, discussed earlier, ${ }^{75}$ plays a significant role in analyzing the globe's ability to fight child trafficking, and child crimes more generally. The Committee on the Rights of the Child normally meets three times a year in Geneva and has a three-week plenary and a one-week presession working group to analyze reports from member countries as well as make recommendations for improvements based on "concluding observations." 76 The Committee also publishes its interpretation of the content of human rights provisions in the form of "General Comments" on issues. ${ }^{77}$

The United Nations has an expansive reach in fighting trafficking as it works through several NGOs. For example, in one part of the globe, "[t]he United Nations Inter-Agency Project on Human Trafficking (UNIAP) works in six countries across the Greater Mekong Sub-Region (GMS): Cambodia, China, Lao PDR, Myanmar, Thailand, and Vietnam."78 UNIAP's headquarters are located in Bangkok, Thailand, but it has an office in each of the GMS country capitals to help police the region. ${ }^{79}$ UNIAP was founded based on objectives to support the regional governments, and, in furthering this objective, it champions the Coordinated Mekong Ministerial Initiative Against Trafficking (COMMIT). ${ }^{80}$ In 2004, to enact COMMIT, the six countries signed a Memorandum of Understanding committing to attack human trafficking by "meeting international standards, highlighting the need for multilateral, bilateral, and government-NGO cooperation."81 COMMIT is now in its third and final phase, utilizing the UNIAP's offices in each GMS country capital as a way to coordinate each country's government action plan with non-governmental agencies that "provide technical and financial assistance to all aspects of the COMMIT Process." 22 GMS is just one region that has profited from the U.N.'s efforts. The key to

74. See id.

75. See Part II.B.

76. Committee on the Rights of the Child: Monitoring Children's Rights, OFFICE OF THE HIGH COMM'R FOR HUMAN RIGHTS, http://www.ohchr.org/EN/HRBodies/CRC/Pages/ CRCIntro.aspx (last visited Oct. 25, 2013).

77. $I d$.

78. UNLAP: Where We Work, supra note 46.

79. Id.

80. See COMMIT: The Coordinated Mekong Ministerial Initiative Against Trafficking, U.N. INTER-AGENCY PROJECT ON HUMAN TRAFFICKING, http://www.no-trafficking.org/ commit.html (last visited Nov. 13, 2013).

81. Id.

82. Id. 
success in globally combating trafficking has been the "wide range of multi-sectoral partners . . . including U.N. agencies, NGOs, inter. governmental organizations, donor organizations, and academia." 83 In March 2007, the U.N. launched the United Nations Global Initiative to Fight Human Trafficking (UN.GIFT) to promote the global fight on trafficking. ${ }^{84}$ It was launched by the International Labour Organization (ILO), the Office of the United Nations High Commissioner for Human Rights (OHCHR), the United Nations Children's Fund (UNICEF), the United Nations Office on Drugs and Crimes (UNODC), the International Organization for Migration (IOM), and the Organization for Security and Cooperation in Europe (OSCE). ${ }^{85}$ UN.GIFT champions the idea that trafficking is so atrocious it cannot be dealt with alone. Countries, agencies, and NGOs representing regions all over the world support it financially and logistically. ${ }^{86} \mathrm{~A}$ multi-agency approach is most effective.

\section{The Vietnamese Government}

A look at Vietnam's position in combating child trafficking illustrates an enforcement system that has been influenced by the United Nations. Child trafficking more easily takes hold in countries like Vietnam, a GMS country, because victims are readily accessible for their "socio-economic vulnerability factors that contribute to human trafficking." 87 Some of these factors include poverty and indebtedness, lack of awareness or education, family breakdowns, and external factors like peer pressure.88 Vietnam has experienced a "feminization' of migration (footnote omitted) particularly for domestic, agricultural and factory work, as well as for marriages." 89 There has been an increase in demand for Vietnamese children for several reasons. First, and more

83. Id.

84. UN.GIFT, UN.GIFT.HUB, http://www.ungift.org/knowledgehub/en/about/index. html (last visited Nov. 9, 2013) (outlining the formation and purpose of the United Nations Global Initiative to Fight Human Trafficking).

85. Id.

86. Id (explaining UN.GIFT is financially supported by several countries including the United Arab Emirates, Canada, Switzerland, Australia, Austria, and UNICEF and was founded by multiple agencies who are bonded by the same mission: eradicate human trafficking, reduce vulnerability of victims, ensure protection for victims, support prosecution of traffickers, and respect human rights).

87. Vietnam, HUMANTRAFFICKING.ORG, http:/www.humantrafficking.org/countries/ vietnam (last visited Nov. 9, 2013).

88. Id.

89. SIREN Human Trafficking Data Sheet: Vietnam, U.N. INTER-AGENCY PROJECT ON HUMAN TRAFFICKING, (Nov. 2008), http:/www.no-trafficking.org/content/SIREN/ SIREN_pdf/vietnam\%20datasheet\%20final\%20november\%202008.pdf. 
specifically, children are targeted for prostitution because suppliers desire virgins as sex workers due to the rise of HIV/AIDS. ${ }^{90}$ Second, young Vietnamese girls are wanted as wives based in large part on the "female deficit" that exists in China and "the lure of promised bride prices." 91 Children have also been targeted for intracountry adoption facilitated through "counterfeit adoption documents for the trade of children."92

"In January 2012, Vietnam's Prime Minister approved the new fiveyear National Plan of Action on Human Trafficking."93 While the Vietnamese government recently passed new anti-trafficking legislation and implemented a number of structural reforms, "there remains a lack of tangible progress in the prosecution of trafficking offenders and protection of trafficking victims." 94 This could be in part because the only legislation Vietnam has on trafficking is located in their Penal Code: in article 119 (Trafficking in Women) and article 120 (Trading in, Fraudulently Exchanging or Appropriating Children).95 Either one of two competent authorities, the Ministry of National Defence, which is law enforcement on land and near sea borders, or the Ministry of Public Security (MPS), which operates at international airports, must identify victims and traffickers and subsequently prosecute traffickers under the Supreme People's Procuracy (SPP). ${ }^{96}$

The Vietnam Penal Code places criminal liability on "[t]rafficking in women," in article 119 , and also "[t]rading in, [f]raudulently exchanging or [a]ppropriating children" in article 120; yet, there are blatant issues with these penal codes. ${ }^{97}$ Vietnam's narrow legislation in Article 119 and Article 120 originally excluded men by using the term "trafficking in women" when it could have classified victims as "humans" or children.98 The Vietnamese government's original law indicates the prevailing view that victims are women and children. The National Congress of Vietnam amended article 119 to include "trafficking in humans," and recognized that males are indeed subject to trafficking. ${ }^{99}$

90. See id.

91. Vietnam, supra note 87.

92. SIREN Human Trafficking Data Sheet: Vietnam, supra note 89.

93. Vietnam, supra note 87.

94. Id.

95. Child Exploitation \& Online Prot. Ctr. In Ass'n with the British Embassy,

HaNoI, The Trafficking of WoMEn AND Children From VietNaM 7 (2011).

96. See id.

97. See id.

98. See Charles Tucker et al., An Analysis of Human Trafficking for Sexual Exploitation in Vietnam and a Comprehensive Approach to Combating the Problem, 16 U.C. DAVIS J. INT'L L. \& POL'Y 437, 457 (2010).

99. See id. 
The article lists aggravating factors of "trading in, fraudulently exchanging or appropriating children," but it does not define "child trafficking." 100 These two articles are not enough to adequately prosecute traffickers; therefore, Vietnam uses the following other crimes in the Vietnamese Penal Code to decrease trafficking: "harboring" or "procuring a prostitute"; "crimes relating to document fraud"; "rape against children"; "organizing underage marriages"; and "coercing persons to stay in foreign countries." 101

Legislation in Vietnam is relatively recent, and many amendments are necessary to narrow its definition of trafficking. Vietnam has already made some amendments, which have moved it toward a broader understanding of trafficking, including adding men in its codes; however, Vietnam must define child trafficking in a more descriptive way that helps government officials, law enforcement, and other patrol agents to identify child trafficking throughout the country. Too often, child trafficking appears legitimate. For example, Hieu, a male from the small village of Dien Bien located in the mountainous northwestern part of Vietnam, was exploited for domestic labor at age sixteen. ${ }^{102} \mathrm{He}$ explained, "My parents were happy I could go and earn some money."103 However, his method to "earn some money" consisted of "two years locked in a cramped room making clothes for a small garment factory with no wages," and if he messed up, "they would beat [him] with a stick."104 More fact-specific child trafficking laws will help Vietnam clarify the line between legitimate domestic work to bring the family money and exploitation of children, like Hieu, for labor in dangerous, oppressive conditions.

\section{Ghana}

In another area of the world, Ghana, Africa, trafficking originated for two primary reasons. First, families have traditionally sent their children to live with extended family members to build up ties, enhance education, or develop skills; however, this tradition is now abused and children are often exploited for the usual reasons. ${ }^{105}$ Second, Ghana's

100. See Trading in, Fraudulently Exchanging or Appropriating Children, VIETNAMESE PENAL CODE, Art. 120 (1999), available at http://www.vietlaw.biz/bldisplay/db1/ show_clause.php?id=39500\&indexid $=\&$ doc $=1640$.

101. Tucker, supra note 98 , at 459-60.

102. See Marianne Brown, Vietnam's Lost Children in the Labyrinth of Slave Labour, BBC, (Aug. 27, 2013, 10:39 AM), http:/www.bbc.com/news/world-asia-23631923.

103. Id.

104. Id.

105. Manda Sertich \& Marijn Heemskerk, Ghana's Human Trafficking Act: Successes and Shortcomings in Six Years of Implementation, 19 NO. 1 HUM. RTS. BRIEF 2, 2 (2011). 
severe poverty has led many individuals to seek work outside of their communities, which has made them susceptible to trafficking. ${ }^{106}$ In addition to the ordinary forms of exploitation such as domestic labor, street peddling, mining, working in chop bars (food stands), and sexual exploitation, thousands of children between the ages of three and seventeen are trafficked to the Volta Region to help with the fishing industry. 107 They work extremely long hours in dangerous conditions and are often sent by parents who do not realize the conditions, but even if they did, need the twenty-five to sixty-five dollars their children earn for five years of service work. 108

Following the U.N. Palermo Protocol, Ghana's Ministry of Women and Children's Affairs (MOWAC) enacted its first legislation to combat human trafficking in 2005, which is modeled much like the Protocol in that it has the three goals: to prevent, protect, and prosecute. ${ }^{109}$ Ghana's legislation, similar to Vietnam's, lacks a clear definition of trafficking. Section 1(1) of Ghana's law defines trafficking, yet it misplaces an "or," leaving advocates to different interpretations of the law.110 Some interpreters read the conjunctive "or" to mean that there are many forms of trafficking that will validate a claim, such as "recruitment OR transportation OR transfer OR [harboring] ..." whereas others link the "or" to a latter part of the statute and assume that all the forms listed previously (recruitment, transportation, transfer, etc.) must be present to allege trafficking exists.111 In the latter instance, prosecuting trafficking would be extremely challenging because the state would have to prove many forms of trafficking had occurred.

An ambiguous definition of trafficking hinders awareness of Ghanaians because it is unclear what behavior constitutes trafficking; it negatively affects law enforcement because they, too, cannot identify trafficked behavior; and it wrecks the ability to differentiate trafficking crimes from lesser crimes that are met with softer punishments. ${ }^{112}$ In addition, some advocates are concerned that the Act is not broad enough in its definition. ${ }^{113}$ There are many forms of child trafficking in Ghana that require unique emphasis, such as the use of child labor in the kayayo business. ${ }^{114}$ Other countries, like Nigeria, have had success with

106. Id.

107. Id.

108. Id. at $2-3$.

109. See id. at 2.

110. See Human Trafficking Act of 2005 (Act 694) (Ghana).

111. See id.; see also Sertich \& Heemskerk, supra note 105 , at 3.

112. See Sertich \& Heemskerk, supra note 105 , at 3.

113. Id. at 4.

114. See id. at 2 (explaining that the kayayo business, the business of head portering, or street peddling, often times employs trafficked children from rural areas to the 
specifically defining forms of exploitation to help with identification and prosecution of child trafficking forms in their own countries. ${ }^{115}$ If Ghana could take another step forward and supplement its trafficking law to include a child-centered portion, government officials could more adequately attack child trafficking in the region.

\section{REMEDIES: FIRST AND FOREMOST, AN ADOLESCENT'S BEST INTERESTS ARE KEY}

The solution to child trafficking, or the exploitation of children for their vulnerabilities, is complex and multifaceted. Nations need to focus on the children themselves and their rights. Governments, NGOs, and U.N. affiliates must enable and empower children to rise above their vulnerabilities to stay protected from traffickers. The correct way to do this is to give children rights and adequate child protection services; consequently, prosecution of traffickers should follow. Countries on continents in the Eastern Hemisphere have looked to the United States and the United Nations for the initiatives set out in the Palermo Protocol and TVPA. These eastern countries are making strides in legislation, most notably in their penal codes, to prosecute traffickers. In comparison to current laws, what is in the best interests of adolescents is a more precise, targeted focus on the vulnerabilities of children and the many forms child trafficking can take. The United States should take this more precise aim to identify child trafficking and stop it from perpetuating.

Once child trafficking victims have been identified, they must be empowered with rights to help them overcome their vulnerable states and move toward a life of opportunity and rehabilitation. The child's rights must not solely be quashed by the parents' or state's determination, but instead, parents and states must recognize that the child deserves the opportunity to exercise his fundamental substantive due process rights, like the right to bodily integrity and freedom to privacy and association, as well as procedural due process rights. If all children are afforded counsel, they will be able to exercise their own rights while assuaging concerns that children are too incompetent to know their own best interests. The best interests of the adolescent should come from exercise of the child's rights first and foremost.

metropolitan cities. Estimates have tens of thousands of Ghanaian children, usually lured by the promise of pay, working in kayayo, a business that ultimately results in sexual exploitation of young girls).

115. See id. at 4 (explaining that Nigeria specifies nine different types of exploitation for its human trafficking law to help with recognition and prosecution efficiency). 
Better identification requires two different types of identification: (1) identification of traffickers who must be met with harsh prosecution; but more importantly, (2) identification of child victims who are not "abusing the system" for attention, illegally immigrating, or knowingly participating in crimes like prostitution. How well do governments and agencies know the victims? Unfortunately, not well enough. Legislators and lobbyists combatting child trafficking must research to better understand the circumstances surrounding the child victims and create legislation that will identify trafficking methods, trafficking victims, and traffickers. In addition, a focus on children's vulnerabilities, specifically those of adolescents who are more psychologically susceptible to harm, must be met with child protection services that enable and empower children.

\section{A. Better Legislation Can Slow Child Trafficking}

The TVPA, with its yearly TIP Reports, provides a lot of the guidance in combatting human trafficking. However, it is only a mechanism to combat human trafficking. The United States Federal Criminal Code punishes child trafficking in its forms of exploitation such as "prostitution, pornography and sexual performance"; 116 however, sixty percent of child trafficking cases are not prosecuted at the federal level. ${ }^{117}$ Thus, the states have increasingly passed their own legislation to provide a framework for stopping child trafficking. One way states have done this is to eliminate the requirement of proof of coercion, or force, as an element to prosecute child traffickers, much as they did with rape laws. ${ }^{118}$ This lower burden of proof enables prosecutors to catch traffickers without putting a burden on the trafficked victim, and consequently provides more protection for the adolescent victim.

More importantly, the TVPA should, as a global example, provide a supplemental Child Victims Protection Act to guide countries like Vietnam and Ghana in taking specific measures to identify child trafficking. In fact, Congresswoman Lucille Roybal-Allard, Representative for California's fortieth congressional district, has already proposed this idea. H.R. 2624 is a bill proposed to the House of Representatives titled, "Child Trafficking Victims Protection Act," but

116. Stacy Teicher Khadaroo, States Toughen iLaws Against Child Sex Trafficking, THE CHRISTIAN SCI. MONITOR (Nov. 8, 2013), http://www.csmonitor.com/USA/Politics/2013/ 1108/States-toughen-laws-against-child-sex-trafficking-video.

117. Id.

118. See id. 
was initially introduced on June 16, 2011, as H.R. 2235.119 The bill not only requires specialized training for all Department of Homeland Security personnel who encounter unaccompanied children, which would greatly improve identification challenges (discussed above), ${ }^{120}$ but also sets forth protections and rights for children, such as "qualified resources and child welfare professionals at appropriate ports of entry . . . confidentiality, ... [and] access to counsel . . ."121 This bill would be instrumental in supplementing general human trafficking laws in a way that identifies child trafficking more narrowly and effectively and truly helps young victims. In addition, it recognizes the child's ability to invoke procedural and substantive due process rights. However, it was not enacted.122 To clarify expectations and dimensions of child trafficking globally, this bill ought to be enacted. The United States has taken up the task of evaluating countries yearly into tiers based on improvements to combat trafficking; therefore, it is especially apparent that the United States should have more leadership in the fight for the victims of trafficking that are most vulnerable-children.

If the United States implements a Child TVPA that outlines specific forms of child exploitation, specific rights of children (like the fundamental right to privacy and adjudicative rights to counsel), and special services that must be offered to child victims upon discovery, then governments around the globe will have a format to help with victim identification, recognition, and rehabilitation. As is apparent from the study of Vietnam and Ghana, ${ }^{123}$ other countries are already beginning to target child trafficking in its forms particular to that country (e.g., Ghana and children in the kayayo business). If the United States would supplement the TVPA with a Child TVPA and evaluate countries' efforts at child trafficking as an additional part of their yearly TIP Report ratings, there could be a noticeable decrease in child trafficking.

119. See H.R. 2235, 112th Cong. (2011), available at http://www.gpo.gov/fdsys/pkg/ BILLS-112hr2235ih/pdf/BILLS-112hr2235ih.pdf.

120. Supra Part II.A. (which explains one of the biggest obstacles in fighting child trafficking is the ability to identify the victims).

121. Summary of the Child Trafficking Victims Protection Act, GovTRACK.US, https://www.govtrack.us/congress/bills/113/hr2624/summary (last visited Mar.. 11, 2015).

122. H.R. 2624 (113th): Child Trafficking Victims Protection Act, Gov'rRaCK.US, www.govtrack.us/congress/bills/113/hr2624 (last visited Mar.. 11, 2015) (providing government tracking and bill analysis that reveals this bill was not enacted).

123. Refer to the discussion supra Part III.C.,D. 


\section{B. A Necessary Shift for Child Rights: Ratify the CRC}

In light of this Note's analysis of case law on children's rights in the United States, it is not surprising that the TVPA skips over the opportunity to textually recognize empowerment for child trafficked victims and set a global example in that regard. Additionally, it is unsurprising that Congress did not pass the Child Trafficking Victims Protection Act, introduced in 2011.124 The U.S. approach to child welfare and the law is one based on the "best interests of the child." Yet, as case law has shown, the "best interests of the child" are usually defined by the parents' desires, and if not the parents', the state's. However, this is not the most effective approach to meet children's best interests. The children should be empowered and given an opportunity to exercise their own rights. Recognizing children's rights is in their best interests. The U.S. government's reluctance to empower children with resources and voice also results from its tendency to view rights as negative rather than positive.

\section{Ratify the CRC: A Move Made in the Best Interests of a Child}

Why not allow children a role in helping achieve what is in their own best interests? "Children who have experienced child trafficking or CSE [commercial sexual exploitation] . . . are a valuable resource for those .. . implementing preventive interventions and should be a primary source of information on which to base programs and policies. . . ."125 Trafficked children can offer their own first-hand experiences of how they were recruited or what services helped them recover the most. In this way, child survivors can provide invaluable direction for new policies. ${ }^{126}$ The Committee on the Rights of the Child, picking up on this idea, just improved its ability to give children a voice: "The Committee will soon be able to consider individual complaints by children."127 Children will be encouraged to express their views and become a part of the trafficked victims' rehabilitation process to help inspire others who have survived similar situations.

Unfortunately, the United States, along with only one other country in the United Nations, is not a member of the Convention on the Rights

124. Id.

125. Yvonne Rafferty, Child Trafficking and Commercial Sexual Exploitation: A Review of Promising Prevention Policies and Programs, 83 AM. J. ORThOPSYChIATRY 559, 570 (2013).

126. See id.

127. OFFICE OF THE HIGH COMM'R FOR HUMAN RIGHTS, supra note 76. 
of the Child. ${ }^{128}$ The United States should have an approach to child trafficking that empowers youth, much like the CRC is attempting to do with support from its 194 signatories. ${ }^{29}$ Such an approach by the United States would entail an opportunity for children to have legislative recognition of their own specific vulnerabilities that lend them to trafficking, as well as provide them with adjudicative rights upon identification to overcome the once vulnerable, exploitative state in which they lived. For example, this would come with recognition of a child's fundamental substantive due process right to freedom of privacy in revealing hurtful information, but it would also afford the child the U.S. tradition of privilege to citizens who share confidential information with clinical care providers. 130

Moreover, the United States would benefit from ratifying the CRC. Parental rights groups voice major opposition to joining based primarily on fears of U.N. interference in U.S. laws and families. Opponents have also proposed an amendment to the U.S. Constitution to protect parents' rights. ${ }^{131}$ "The biggest worry appears to be that the treaty will undermine parental rights even though the Convention explicitly grants responsibilities and protections to parents and guardians." 132 With case law that shows the U.S. trend to hold out a parent's right to determine the best interests of a child, it is not surprising that there is opposition to enabling children more rights like those afforded by the CRC. As detailed earlier in this Note, landmark cases like Pierce v. Society of Sisters and Troxel v. Granville show the United States' dedication to a parent's fundamental rights in deciding what is best for a child. ${ }^{133}$

128. CRC Ratifications, CHILDREN'S RIGHTS, http://unchildrights.blogspot.com/2011/01/ chronological-order-ratifications-crc.html (last visited Mar. 12, 2015).

129. UN Convention on the Rights of the Child, PARENTALRIGHTS.ORG, http://www.parentalrights.org/index.asp?Type=B_BASIC\&SEC $=\{98172987-5 \mathrm{D} 33-4 \mathrm{~A} 41$ AF04-84F6726222C3\} (last visited Nov.. 9, 2013).

130. See Child Trafficking Victims Protection Act, H.R. 2624, 113th Cong. § 2(i) (2013), available at https:/www.govtrack.us/congress/bills/113/hr2624/text (explaining that children would be afforded confidentiality and privacy under the proposed bill).

131. See The Parental Rights Amendment, PARENTALRIGHTS.ORG http://www. parentalrights.org/index.asp?Type=B_BASIC\&SEC=\%7B4771B53E-D345-4753-BEF4-

68C1CA71CE13\%7D (last visited Nov. 24, 2013) (showing the parental rights organization's proposed amendment to the U.S. Constitution that advocates an enumerated fundamental right to rear children and determine the best interests of the child while specifying that no other treaties will limit a parent's right to rear his child).

132. Lawrence J. Cohen \& Anthony T. DeBenedet, Why Is the U.S. Against Children's Rights?: America Refuses to Adopt U.N. Guidelines That It Helped Draft More Than 20 Years Ago. Are We Still in the Dark Ages?, TTME (Jan. 24, 2012), http:/ideas.time.com/ 2012/01/24/why-is-the-us-against-childrens-rights/print/.

133. See generally Troxel v. Granville, 530 U.S. 57 (2000) (holding that Washington state's law allowing any person to petition its courts for visitation rights violated a mother's substantive due process rights); Pierce v. Soc'y of Sisters, 268 U.S. 510 (1925) 
There is another legal conceptual difference between the United States and CRC's approach to child's rights. The CRC more often uses positive rights for children; yet, the United States was founded on negative rights, or natural rights enumerated in the U.S. Constitution. Negative rights, such as the right to life, liberty, and property, afford a citizen the right to not be estopped from doing something; negative rights prevent the government from interfering. For example, the right to bear arms is the right to take up arms without interference from the government. In contrast, positive rights are rights that impose duties on others, usually the state. This can include the right to education or the right to counsel. Individual rights, found in the Bill of Rights and the Fourteenth Amendment, in which the Due Process Clause is grounded, recognize negative rights for citizens. ${ }^{134}$ An example of a negative approach to rights with children is found in the Supreme Court's decision in DeShaney $v$. Winnebago County Department of Social Services. ${ }^{135}$ In DeShaney, the Department of Social Services ("DSS") had prior notice of abuse inflicted by a father on his son but did not act to interfere with the child-parent relationship or remove the child from his father's custody. ${ }^{136}$ This abuse resulted in severe mental retardation; however, the Court ruled, "the State had no constitutional duty to protect [the child] against his father's violence . . .."137 The state had no duty to interfere or take the child from his father's custody.

The United States' negative approach to rights inevitably creates incompatibility with the CRC's focus on child rights, child protection services, and child welfare initiatives-all positive rights. One extreme example is Article 4 in the CRC. It reads, "[w]ith regard to economic, social and cultural rights, States Parties shall undertake such measures to the maximum extent of their available resources . ..."138

This requirement of the CRC, just as one example, conflicts a great deal with the concept of "no affirmative duty to interfere" as seen in the DeShaney case. Nonetheless, the CRC promotes proactive efforts to prevent child trafficking, and child trafficked victims require this

(explaining the Oregon law that required all children attend public school until age 16 interfered with the liberty of parents and guardians to direct the upbringing of and education of children under their control).

134. For more information on positive and negative rights see David $P$. Currie, Positive and Negative Constitutional Rights, 53 CHI. L. REV. 3 (1986).

135. See generally DeShaney v. Winnebago Cnty. Dep't of Soc. Servs., 489 U.S. 189 (1989).

136. See generally id. (holding that a state has no constitutional duty to protect a child from his father after being made aware of possible abuse).

137. Id. at 202.

138. Convention on the Rights of the Child, G.A. Res. 44/25 (IV), U.N. Doc. A/RES/44/25 (Nov. 20, 1989). 
positive rights approach. The importance of opportunity for education and access to mental and physical health services, as well as counsel for court proceedings (to name a few necessary positive rights), must be conceded to enable change in children's lives. Although philosophically and theoretically inconsistent with the United States' approach to rights, a positive approach to rights is necessary to reach the best interests of child trafficked victims and should not deter U.S. involvement.

By refusing to join the CRC, the United States is sending a global message that a child's voice is not as important as his parents'. Yet, despite the criticisms of parental rights activists, both parental rights and children's rights can be protected by the Convention. President Obama, Secretary of State Hillary Clinton, and U.N. Ambassador Susan Rice all expressed approval of ratification of the CRC, yet the Administration has not moved the process forward. ${ }^{139}$ In ratifying the CRC, the United States can "propose a set of Reservations, Understandings, and/or Declarations (RUDS). "These provisions [will] include any specific additions, changes or deletions in the language and substance .. . that the US will require" to ratify the CRC. ${ }^{140}$ The United States can find comfort in the ability to make the CRC treaty more compatible with its ideals and possibly overcome the inconsistent nature of awarding positive rights.

Even if the United States does not ratify the CRC due to differences in legal approaches and the philosophical underpinnings of those laws, such as positive versus negative rights, the United States should use the CRC's concepts in its own laws to empower children and create within them a sense of agency. The United States can still embody the principles in the CRC by creating laws that more narrowly address the needs of adolescents and better protect them by allowing them to have a voice. The U.S. government must stop standing still when it comes to empowering youth. If children's individual rights are recognized, they alone can transform their circumstances to be full of opportunity and hope for the future.

139. Ask the President to Get the Ball Rolling, CONVENTION ON THE RIGHTS OF THE CHILD, http://www.childrightscampaign.org/take-action/ask-the-president (last visited Nov. 22, 2013).

140. How Does the United States Ratify Treaties?, Convention on THE RIGHTS OF THE CHILD, http://www.childrightscampaign.org/why-ratify/how-does-the-united-states-ratifytreaties (last visited Nov. 22, 2013). 


\section{Checking Necessary Child Rights}

Lawmakers must define the specific parameters of the rights afforded to children. A child trafficked victim, in particular an adolescent, as has been emphasized, is extremely vulnerable. This vulnerable state can be transformed to one of empowerment if the child is afforded all fundamental rights like freedom of privacy in regard to revealing information that is unpleasant or embarrassing; freedom to associate in regard to the ability to choose family ties and relationships; and also procedural due process rights like right to counsel, notice, and the right to participate in adjudicative proceedings against traffickers. Children will only be empowered once given a position of agency in transformation from a victim state.

Despite this need to empower children with rights, there is a competing concern. It is precisely because children are vulnerable, psychologically less stable, and subject to peer pressure that they need a check on their abilities to determine what is in their own best interests. This concern, echoed by parental rights groups, is valid. How do human rights advocates make sure that children who are enabled with rights do not use them to their detriment? The answer is simple-counsel. One of the most rewarding gifts to a child is an advocate that looks out for his best interests while informing him of his constitutional rights. Sometimes this can be a parent or guardian. In other instances, like a case involving a trafficked child, parental or guardian counsel is not an option. If each trafficked child is given the due process right to counsel, notwithstanding parental presence, he will be ensured a check on his ability to exercise his rights while experiencing empowerment and voice in his transition from adolescence to a life as a contributing member of society.

It is true that the child's parents, who desire to rear the child a certain way, might sway a trafficked child's counsel; similarly, the state will undoubtedly influence counsel to help protect the child's best interests in a certain way. Yet, influence from parents and the state will not necessarily create a negative impact on the trafficked child; moreover, counsel will be present to act as an individual advocate and advisor for the child, advocating his best interests while also giving the child an ability to exercise his constitutional rights. It is improper for U.S. courts to only consider the parent's fundamental rights when dealing with children and the law. It is not unreasonable to think that a child's fundamental rights should be protected. With the use of counsel, concerns will be matched and the adolescents' best interests still pursued. 


\section{Child Protection Services: Overcoming Barriers}

After establishing a more efficient process to identify trafficked children through legislation that sets out specific characteristics of child trafficking (suitable for each country), children must be rehabilitated into society to enable them to contribute to society in the future. Rehabilitation is a more difficult challenge for child victims who already maintain so many vulnerable traits: language barriers, feelings of guilt, feelings of confusion, fear of deportation, or apprehension of traffickers who can revictimize them. In fact, in the United Kingdom, approximately 60 percent of trafficked children in local authority care go missing, ${ }^{141}$ and nearly one-third of "trafficked children that go missing disappear from care in less than one week." 142 Children, especially vulnerable adolescents who have generally been neglected and left accessible to trafficking, require "practitioners supporting young people who are making the transition from vulnerable 'victim' to independent autonomous agent" to ensure they escape a life of trafficking. ${ }^{143}$

However, reports indicate that services are not sufficient for victims of trafficking. One such report, "After Trafficking: Experiences and Challenges in the (R)eintegration of Trafficked Persons in the Greater Mekong Sub-Region," backed by the United Nations, revealed from interviews with 250 survivors that "[w]hen support is provided in a way that does not respect the will of the victims, or is even provided against their will, this may result in further trauma and a continuation of their victimization." 144 This is especially true for adolescents who may be misunderstood or stigmatized for their life choices. The U.N.-backed report goes on to further warn, "Any support offered to victims of trafficking needs to be given in a way that restores a sense of control for the victims over their own lives." 145

Researchers who conducted a case study of child trafficked victims, specifically adolescents, in the United Kingdom explained how services can fail when trying to empower child trafficked victims. Three different issues affect the success of services:

141. Christine Beddoe, ECPAT UK, Missing Out: A Study of Child Trafficking iN THE NORTH-WEST, NORTH-EAST AND WEST MIDLANDS 20 (2007).

142. THE CTR. For SOC. JUSTICE, It HAPPENS HeRE: EQUTPING THE UNITEd Kingdom TO FIGHT MODERN SLAVERY 194 (2013).

143. See PEARCE ET AL., supra note 1, at 3 (noting the complexities identified by practitioners as trafficked victims develop from adolescence to adulthood).

144. Not Enough Done to Reintegrate Victims of Human Trafficking, UN-Backed Report Warns, U.N. NEwS CENTRE (Oct. 14, 2013), http://www.un.org/apps/news/ story.asp?NewsID=46263.

145. Id. 
[S]ervice providers may not welcome young people, who may be feared or seen as too difficult to engage; young people themselves may feel hostile towards or alienated from services designed to support them; and, more specifically in relation to child protection, services may focus on safeguarding younger children perceived to be the most vulnerable, overlooking the needs of older adolescents. ${ }^{146}$

Children must be met with specialists who are trained to help them transition from child trafficked victims to young adults in society. It is a delicate time for the child, and with adolescents, it is unclear why some resort to silence, building a wall that hinders recovery. The child may feel he is not a victim, that child protection services may not be able to help him, or a strong affinity for his trafficker; but child services providers must persist in providing aid to which the trafficked child victim acts receptive. By amplifying attention given to child protection services and child rehabilitation into society, youth will be empowered to overcome the wrongs that befell them or at least go on to lead meaningful, hopeful lives.

\section{CONCLUSION}

Child trafficking can be diminished in a number of ways. Moreover, the strategy must remain dedicated to the best interests of children to achieve success in their lives. First, governments, and the United States in particular, must make a global effort to clarify specific characteristics of child trafficking in legislation. There are many misconceptions and stereotypes of trafficking that must be corrected to rid the world of child trafficking: the concept of smuggling versus trafficking, the misunderstanding that males are not exploited, and the realization that exploitation comes in many forms, not just sexual exploitation. By using legislation that is intelligently crafted to specifically highlight characteristics of child trafficking and its forms for that region, officials and specialists will be able to recognize child trafficking and help increase the identification of trafficked victims. When identification of adolescent victims is more accurately executed and realizes the sensitive deportation threats that loom in the minds of adolescents, information will flow more freely, and this will ultimately trigger prosecution and reduce adolescent victims.

146. PEARCE ET AL., supra note 1 , at 9. 
Second, the United States has a lead global role to play that begins with ratification of a Child TVPA and the CRC to show support in recognizing child's rights. Even if the United States does not adopt the CRC, its concept of enabling adolescents with rights and voice can be carried over into the U.S. legal framework. Youth should be empowered with constitutional rights that are given to all citizens and fundamental due process rights that are not only substantive, but also procedural. To protect adolescents and children from their vulnerabilities and incompetences in exercising rights, all children must be afforded counsel. With an advocate that not only helps the child exercise his rights, but also acts in the child's best interests, children will be empowered in society and will be able to take agency in their lives.

Last, children and adolescent trafficked victims should be afforded specialized services that help them regain control of their lives while offering their voices to help future victims. The threat of revictimization is too severe. Specialists must not back away from the challenge of adolescent victims who need help the most. With this approach, adolescent victims have a chance to achieve rehabilitation and conquer threats of revictimization while playing a role in the process. By adopting these remedies, the United States can better lead the globe in advocating a trafficked adolescent's best interests. 